\title{
A Tetracoordinated Phosphasalen Nickel(III) Complex
}

\author{
Thi-Phuong-Anh Cao, Grégory Nocton, Louis Ricard, Xavier F. Le Goff, and Audrey Auffrant*
}

((Dedication----optional $))$

N,N'-bis(salicylidine)ethylenediamine (salen) derivatives constitute a very successful class of ligand that have found numerous applications in inorganic chemistry and catalysis. ${ }^{[1]}$ Its extraordinary popularity comes from its easy synthesis, allowing a variety of skeleton variations, and its ability to coordinate a great number of different metal ions. Moreover the presence of two phenoxy and imine functions is reminiscent of the coordination environment generated by two histidines and two tyrosines, encountered in several enzymes. Thus, 15 years ago, the one-electron oxidation of a (salen)copper(II) was described, and the resulting persistent phenoxy radical was established as a biomimetic functional model of galactose oxidase. ${ }^{[2]}$ Since then, one-electron oxidized salen metal complexes of first-row transition metals have received considerable attention. ${ }^{[3]}$ Depending on the nature of the redox-active orbitals, oxidation of salen complexes leads either to high valent metal (metal centered oxidation) or metal-ligand radical species (ligand centered oxidation). Therefore, various factors may affect the oxidation locus, as it was nicely illustrated in the case of nickel salen complexes. In non coordinating solvents, one electron oxidized nickel salen complexes are generally highly delocalized ligand radical species with a contribution of the nickel orbitals. ${ }^{[3 \mathrm{~b},}$ 4] However, in coordinating solvents, or in the presence of exogenous ligands such as pyridine or coordinating anions, the geometry of the complex is modified and so does the locus of the oxidation, allowing the formation of $\mathrm{Ni}^{\mathrm{III}}$ complexes. ${ }^{[4 a, b}$, 5] Temperature dependant behaviour, viz. valence tautomery, was also described in a few examples. ${ }^{[5 b, 6]}$ Moreover, the overall electronic distribution may be finely tuned by the substituents of the phenoxy rings. They influence not only the oxidation locus (which takes place at the most electron rich phenoxide) as evidenced with complexes featuring unsymmetrical salen, ${ }^{[3 c, 7]}$ but also the extent of the radical delocalization. ${ }^{[3 \mathrm{~b}, 8]}$ The hybridization of the nitrogen atoms is also of prime importance since it may influence the oxidation locus, the spin state of the metal, and the magnetic interaction within the molecule. ${ }^{[5 b, 9]}$

Astonishingly, despite numerous structural variations proposed for salen ligands, the introduction of heteroatoms in its backbone was

[*] Dr. Thi-Phuong-Ahn Cao, Dr. Grégory Nocton, Dr. Louis Ricard, Dr. Xavier F. Le Goff, and Dr. Audrey Auffrant.

Laboratoire Hétéroéléments et Coordination, CNRS, Ecole Polytechnique, Route de Saclay, Palaiseau, F-91128, France

Fax: (+331 69334440$)$

E-mail: audrey.auffrant@polytechnique.edu

Homepage: www.dcph.polytechnique.fr

[**] CNRS and Ecole Polytechnique are thanked for financial support. We are grateful to ICMMO (Paris-sud Orsay) for giving us the opportunity to measure solid state EPR on its platform and to Pr. Y. Jean for fruitful discussion concerning calculations.

Supporting information for this article is available on the WWW under http://www.angewandte.org or from the author. rarely investigated. ${ }^{[10]}$ As we are interested in iminophosphorane $(\mathrm{P}=\mathrm{N})$ based ligands as alternative to conventional imine ones, ${ }^{[11]}$ we developed a new class of ligand featuring iminophosphoranes in place of imines, which we termed phosphasalen (or Psalen). We have recently demonstrated that these ligands are more flexible and electron-donating than their carbon analogue ${ }^{[12]}$ and that they provide efficient and selective initiators for rac-lactide polymerization. ${ }^{[13]}$ In the present work, we wish to report the synthesis and characterization of a phosphasalen nickel(II) complex and its one electron oxidation which leads to a temperature persistent high valent tetracoordinated $\mathrm{Ni}^{\mathrm{III}}$ complex.

With the objective of studying the oxidation of a [Ni(Psalen)] complex, we chose to use a ligand featuring substituents on the ortho and para positions of the phenoxides in order to increase its stability, and preferred tertbutyl groups for solubility reason. The required phosphasalen ligand $\mathbf{1}$ was prepared following a procedure we recently published. ${ }^{[13 \mathrm{~b}]}$ Reaction of $\mathbf{1}$ with $\left[\mathrm{NiBr}_{2}(\mathrm{DME})\right]$ in THF led, after removal of the potassium salts, to the formation of the nickel(II) complex 2 as a purple solid in $92 \%$ yield (Scheme 1). In the ${ }^{31} \mathrm{P}\left\{{ }^{1} \mathrm{H}\right\}$ NMR spectrum the coordination is indicated by a deshielding of the phosphorus nuclei appearing as a singlet at $\delta\left(\mathrm{CD}_{2} \mathrm{Cl}_{2}\right)=36.0 \mathrm{ppm}$. This complex was characterized by multinuclear NMR spectroscopy, elemental analysis, and X-ray diffraction analysis. As expected for a $\mathrm{d}^{8}$ complex, $\mathbf{2}$ adopts a square planar geometry around the metal with a slight deviation from planarity $\left(8.5^{\circ}\right.$, see $\left.\mathrm{SI}\right)$.

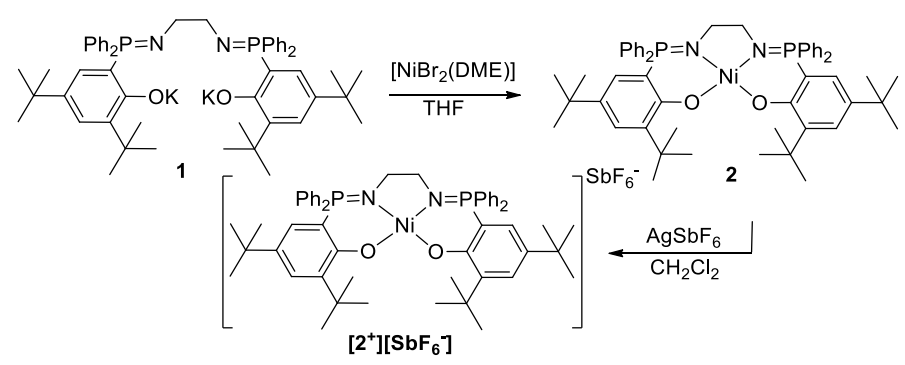

Scheme 1. Synthesis of nickel complexes 2 and $\left[2^{+}\right]\left[\mathrm{SbF}_{6}{ }^{-}\right]$

The cyclic voltammogram of $\mathbf{2}$ exhibits three oxidation waves in $\mathrm{CH}_{2} \mathrm{Cl}_{2}$ at $+0.16,+0.96$, and $+1.22 \mathrm{~V}$ versus ferrocene/ferrocenium $\left(\mathrm{Fc} / \mathrm{Fc}^{+}\right)$. The first oxidation is much easier than the one reported for the related $\left[\mathrm{Ni}\left({ }^{t} \mathrm{Bu}\right.\right.$-salen $\left.)\right](\Delta \mathrm{E} \sim 420 \mathrm{mV}$, table 1$),{ }^{[5 \mathrm{~b}, 14]}$ in agreement with the better electron donating ability of the phosphasalen. Moreover the difference between the first and second oxidation waves of 2 is large $\left(\Delta \mathrm{E}^{1 / 2}=0.8 \mathrm{~V}\right)$ compared to that observed for the salen analogue $\left(\Delta \mathrm{E}^{1 / 2}=0.46 \mathrm{~V}\right){ }^{[5 \mathrm{~b}, 14]}$ In salen nickel complexes, the two first oxidations are known to occur on both phenoxides. Within the $\mathrm{Ni}$ (II) salen complexes series, the rather large separation between the two first half-wave potentials observed for $\left[\mathrm{Ni}\left({ }^{t} \mathrm{Bu}-\right.\right.$ salen)] was interpreted as a result of the strong electronic communication between the two phenoxides. ${ }^{[5 b, 14]}$ Therefore the even larger peak separation observed for $\mathbf{2}$ may indicate that the first oxidation in this complex does not occur on the ligand but may be metal centered. 
Table 1. Electrochemical data for $2\left(3.0 \mathrm{mmol} \mathrm{L}^{-1}\right.$ in $\mathrm{CH}_{2} \mathrm{Cl}_{2}$ $\left.\left[\mathrm{Bu}_{4} \mathrm{~N}\right]\left[\mathrm{BF}_{4}\right]: 0.12 \mathrm{M}^{-1} ; 50 \mathrm{mV} \mathrm{s}^{-1}\right)$ and [Ni('Bu-Salen)] ${ }^{[5 b, 14]}$ Potential values given relative to $E_{1 / 2}\left(\mathrm{Fc}^{+} / \mathrm{Fc}\right)$.

\begin{tabular}{cccc}
\hline Complex & $\mathrm{E}_{1 / 2}{ }^{1}, \mathrm{~V}$ & $\mathrm{E}_{1 / 2}{ }^{2}, \mathrm{~V}$ & $\mathrm{E}_{1 / 2}{ }^{3}, \mathrm{~V}$ \\
\hline $\mathbf{2}$ & 0.16 & 0.96 & 1.22 \\
{$\left[\mathrm{Ni}\left({ }^{\mathrm{B}}\right.\right.$ Bu-Salen)] } & 0.58 & 1.04 & \\
\hline
\end{tabular}

This latter result prompted us to investigate the chemical oxidation of $\mathbf{2}$. The cation $\left[\mathbf{2}^{+}\right]$was synthesized by addition of one equivalent of a silver salt to a $\mathrm{CH}_{2} \mathrm{Cl}_{2}$ solution of 2 . This induced a rapid color change from blue to red-brown. Monitoring the reaction with ${ }^{31} \mathrm{P}\left\{{ }^{1} \mathrm{H}\right\}$ NMR spectroscopy shows the disappearance of the starting material and the formation of a paramagnetic species, whose ${ }^{1} \mathrm{H}$ NMR signals spread in the chemical shifts values already observed for Ni(III) complexes. ${ }^{[15]}$ Variable temperature experiments confirmed the temperature dependence of those chemical shifts. Different silver salts were used and led to similar results nevertheless only $\left[\mathbf{2}^{+}\right]\left[\mathbf{S b F}_{6}\right]$ did crystallize, which encouraged us to focus on this complex. Complex $\left[\mathbf{2}^{+}\right]$is stable for months in the solid state and days in toluene or dichloromethane solution, at room temperature under an inert atmosphere.

Figure 1. ORTEP view of the cation $\left[^{[+}\right]$. The $\mathrm{SbF}_{6}$ anion, solvent molecules and hydrogen atoms have been omitted for clarity. Thermal

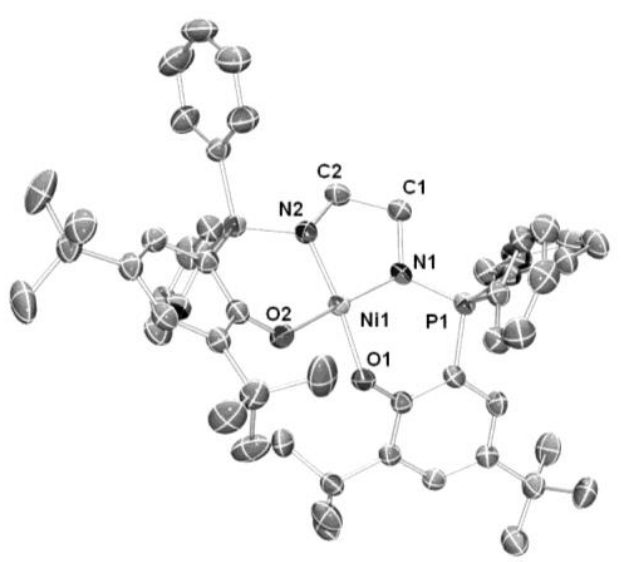

ellipsoids drawn at the $50 \%$ probability level. Selected distances $(\AA)$ and angles $\left({ }^{\circ}\right): \mathrm{Ni}(1)-\mathrm{O}(1) 1.828(2), \mathrm{Ni}(1)-\mathrm{O}(2)$ 1.844(2), $\mathrm{Ni}(1)-\mathrm{N}(1)$ 1.875 (3), Ni(1)-N(2) 1.842(3), $\mathrm{P}(1)-\mathrm{N}(1) 1.639$ (3), $\mathrm{P}(2)-\mathrm{N}(2) 1.650$ (3), O(1)-C(3) 1.327 (4), O(2)-C(30) 1.326(5), N(1)-C(1) 1.486(5), $\mathrm{N}(2)-\mathrm{C}(2)$ 1.486(5), N(1)-Ni(1)-O(1) 94.9(1), O(2)-Ni(1)-N(2) 95.3(1), $\mathrm{N}(1)-\mathrm{Ni}(1)-\mathrm{N}(2)$ 86.8(1), O(1)-Ni(1)-O(2) 84.2(1), O(1)-N(1)-N(2)-O(2) 11.06 .

The ORTEP plot of the cation $\left[\mathbf{2}^{+}\right]$is presented in Figure 1. The nickel ion adopts a slightly distorted square planar geometry (deviation from planarity $\mathrm{O}(1)-\mathrm{N}(1)-\mathrm{N}(2)-\mathrm{O}(2)$ : $\left.11.06^{\circ}\right)$. No stacking interaction or hydrogen bond was observed with the $\mathrm{SbF}_{6}$ anion. The $\mathrm{O}-\mathrm{C}_{\mathrm{Ph}}$ bonds do not vary significantly upon oxidation (1.327(4) $\AA$ and 1.326(5) $\AA$ vs 1.317(3) $\AA$ ) whereas all Ni-O and Ni$\mathrm{N}$ bonds shorten $(1.875(3) \AA$ and $1.842(3) \AA$ for Ni-N and $1.828(2)$ $\AA$ and $1.844(2) \AA$ for $\mathrm{Ni}-\mathrm{O}$ in $\left[2^{+}\right] v s$ 1.887(2) $\AA$ and 1.881(2) $\AA$ in the neutral complex). Interestingly, the contraction of the coordination sphere is not symmetrical, and is stronger along the $\mathrm{O}(1)-\mathrm{Ni}-\mathrm{N}(2)$ axis than on the $\mathrm{O}(2)-\mathrm{Ni}-\mathrm{N}(1)$ one. Noteworthy, the shortening of the Ni-N bond is accompanied by an elongation of the $\mathrm{P}-\mathrm{N}$ bond from 1.619 (2) $\AA$ in 2 to 1.639(3) $\AA$ and 1.650(3) $\AA$ for $\mathrm{P}(1)-\mathrm{N}(1)$ and $\mathrm{P}(2)-\mathrm{N}(2)$ respectively, again $\mathrm{N}(2)$ experiences the largest variation. This may indicate a lower stabilization of the nitrogen lone pairs by phosphorus.

In order to get insights in the structural features of $\mathbf{2}$ and $\left[\mathbf{2}^{+}\right]$, DFT calculations were carried out on both complexes. For the oxidized complex, calculations were carried out with and without the anion giving comparable results (see SI). The geometry optimizations well reproduce the experimental structures, including the non-symmetric contraction of the coordination sphere upon oxidation (see table S6). In the neutral complex 2, the two highest occupied molecular orbitals, which are of similar energy, result from antibonding interactions between the $\mathrm{d}_{\mathrm{xz}}$ or $\mathrm{d}_{\mathrm{yz}}$ orbital of $\mathrm{Ni}$ and $\mathrm{p}_{\pi}$ orbitals of the oxygen atoms (see SI). Upon oxidation this degeneracy is suppressed, as one electron is removed from the orbital featuring an antibonding interaction of the $\mathrm{d}_{\mathrm{yz}}$ orbital of the $\mathrm{Ni}$ and the $\mathrm{p}_{\pi}$ orbitals of $\mathrm{O}(1)$ and $\mathrm{N}(2)$. This explains why the oxidation causes a stronger contraction on this particular axis. Importantly, this coincides with the highest occupied quasirestricted orbital calculated for $\left[\mathrm{Ni}\left({ }^{t} \mathrm{Bu}-\mathrm{Psalen}\right)\right]^{+}\left[\mathbf{2}^{+}\right]$as well as the Mulliken spin distribution, which is mainly concentrated on the $\mathrm{Ni}$ (0.69), $\mathrm{O}(1)(0.13)$, and $\mathrm{N}(2)$ (0.12) atoms. Therefore, from the DFT calculations, and contrary to its salen analog $\left[\mathrm{Ni}\left({ }^{t} \mathrm{Bu}-\mathrm{salen}\right)\right]^{+},\left[\mathbf{2}^{+}\right]$ may be described as a high valent $\mathrm{Ni}^{\mathrm{III}}$ complex rather than a ligand radical metal complex.

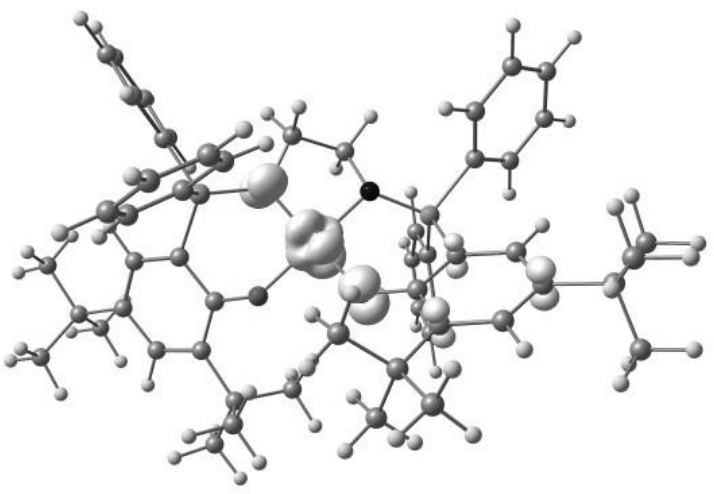

Figure 2. Spin density distribution in complex $\left[2^{+}\right]$

$\mathrm{X}$-Band EPR of $\left[2^{+}\right]\left[\mathbf{S b F}_{6}{ }^{-}\right]$was recorded in a toluene/benzene

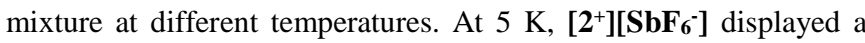
large g-tensor anisotropy (Figure 3) with $\mathrm{g}_{1}=2.29, \mathrm{~g}_{2}=2.215$ and $\mathrm{g}_{3}$ $=2.061\left(g_{\text {iso }}=2.19\right)$, indicative of a $S=1 / 2$ ground state in a rhombic symmetry centered on the nickel ion, i.e. a $\mathrm{Ni}^{\mathrm{III}}$ metal center. When temperature is increased, the EPR signal tends to decrease but no change in the $\mathrm{g}$ strengths have been noted up to $100 \mathrm{~K}$. Above this temperature, the signal is very weak which prevents reasonable simulation and disappears so that $\left[\mathbf{2}^{+}\right]\left[\mathbf{S b F}_{6}{ }^{-}\right]$is EPR-silent at room temperature. Large $g$ values account for significant orbital contributions that allow low lying states to mix through spin-orbit coupling. This is rather usual in $\mathrm{d}^{7}$ complexes, and may also relate to the loss of intensity of the EPR signal at higher temperature. ${ }^{[16,17]}$ In a perfect square planar geometry the $\mathrm{g}$ matrix orientation would be as $g_{x}=g_{y} \gg g_{z} \cdot{ }^{[18]}$ In the case of $\left[2^{+}\right]\left[\mathbf{S b F}_{6}{ }^{-}\right], g_{1}>g_{2} \gg g_{3}$ and indeed indicates a predominance of the xy plane $\left(g_{1}\right.$ and $\left.g_{2}\right)$ over the $\mathrm{z}$ axis $\left(\mathrm{g}_{3}\right)$ but with a significant distortion in the xy plane $\left(\mathrm{g}_{1}\right.$ differs from $\mathrm{g}_{2}$ ). This observation is in good agreement with the X-ray data that feature two different sets of distances in the xy plane for the $\mathrm{N}(1)-\mathrm{Ni}-\mathrm{O}(2)$ and $\mathrm{N}(2)-\mathrm{Ni}-\mathrm{O}(1)$ axes but, unfortunately, no hyperfine coupling with the ${ }^{14} \mathrm{~N}$ and/or the ${ }^{31} \mathrm{P}$ atoms in the $\mathrm{x}$ and $\mathrm{y}$ 
axis could be observed to further sharpen this analysis. Powder EPR of ${ }^{\left[2^{+}\right]\left[\mathbf{S b F}_{6}\right]}$ is also in agreement with a $\mathrm{Ni}^{\mathrm{III}}$ complex (see Supporting Information) ruling out an eventual axial solvent coordination in solution. EPR g-tensor calculations were also performed on $\left[2^{+}\right]\left[\mathbf{S b F}_{6}{ }^{-}\right]$and gave a very similar outcome $\left(\mathrm{g}_{1}=\right.$ $2.34, \mathrm{~g}_{2}=2.21$ and $\mathrm{g}_{3}=2.09, \mathrm{~g}_{\text {iso }}=2.21$; see Supporting Information). As the decrease of EPR intensity signal may have been associated with valence tautomery, ${ }^{[5 b]}$ temperature dependant magnetic data were recorded in the solid state for $\left[2^{+}\right]\left[\mathbf{S b F}_{6}{ }^{-}\right]$. The data show a Curie behaviour over the $4-300 \mathrm{~K}$ temperature range $\left(\chi_{\mathrm{M}}=\mathrm{C} / \mathrm{T}\right)\left(\right.$ See SI). The $\chi_{\mathrm{M}} \mathrm{T}$ value $\left(\mathrm{C}=0.46 \mathrm{~cm}^{3} . \mathrm{K} / \mathrm{mol}\right)$ is a little higher than expected for a $\mathrm{d}^{7}$ low spin complex but can be fitted with a giso value of 2.22 which is in very good agreement with the $\mathrm{g}_{\text {iso }}$ obtained from EPR $\left(\mathrm{g}_{\text {iso }}=2.19\right)$. No decrease of the $\chi_{M} \mathrm{~T}$ value was observed in a $4-300 \mathrm{~K}$ temperature range which reinforces that the oxidized phosphasalen nickel features a $\mathrm{d}^{7}$ high valent $\mathrm{Ni}^{\mathrm{III}}$ which persists upon increasing the temperature.
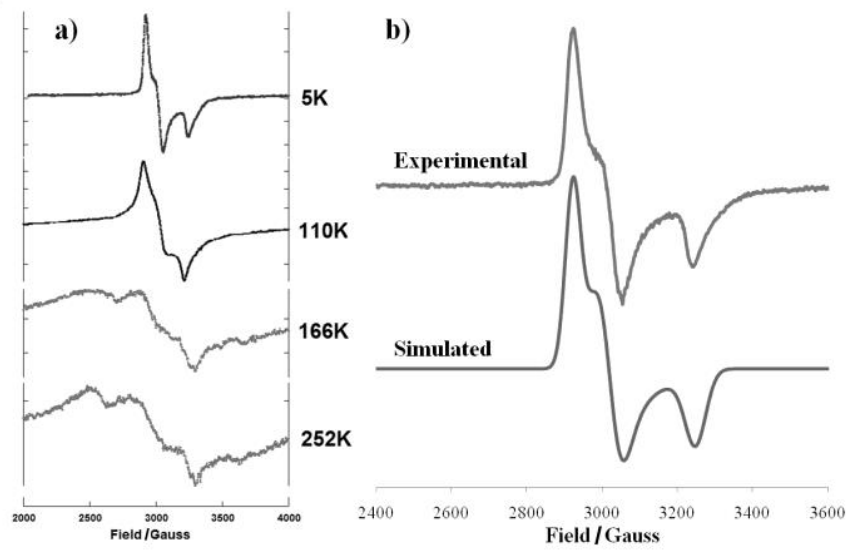

Figure 3. X-band EPR spectra of $\left[2^{+}\right]\left[\mathbf{S b F}_{6}^{-}\right]$at different temperatures. $\left[2^{+}\right]\left[\mathrm{SbF}_{6}^{-}\right]^{-}(4 \mathrm{mM})$ in toluene:benzene, frequency $9.3690 \mathrm{GHz}, \mathrm{P}=$ $0.1 \mathrm{~mW}$ at $5 \mathrm{~K}, 60 \mathrm{~mW}$ at other temperatures. (b) Experimental spectrum (at $5 \mathrm{k}$ ) and simulated one.

Visible spectroscopy was also performed on $\mathbf{2}$ and [2 $\left.^{+}\right]\left[\mathbf{S b F}_{6}{ }^{-}\right]$at room temperature in $\mathrm{CH}_{2} \mathrm{Cl}_{2}$ and toluene. Complex 2 presents two bands at $\lambda_{\max }=565 \mathrm{~nm}\left(17700 \mathrm{~cm}^{-1}\right)$ and $\lambda_{\max }=665 \mathrm{~nm}\left(15040 \mathrm{~cm}^{-}\right.$ ${ }^{1}$ ) (see Figure S4) that account for MLCT charge transfer, typical in nickel(II) square planar complexes. ${ }^{[4]}$ When one electron is removed and $\mathbf{2}$ is oxidized to $\left[\mathbf{2}^{+}\right]\left[\mathbf{S b F}_{6}-\right]$, the purple colour of $\mathbf{2}$ changes to black and is indicative of high absorption in the visible range. The visible spectrum indeed possesses high absorption coefficients and two broad bands centered in toluene at $\lambda_{\max }=490$ $\mathrm{nm}\left(20400 \mathrm{~cm}^{-1}\right)$ and $\lambda_{\max }=990 \mathrm{~nm}\left(10100 \mathrm{~cm}^{-1}\right)$ with absorption coefficients over $5000 \mathrm{~cm}^{-1} \mathrm{M}^{-1}$ (Figure 4). In order to better understand this particular spectrum, a Time-Dependant DFT analysis was performed using the optimized geometry of $\left[2^{+}\right]$ described above. This predicts three principal transitions at 11337 $\mathrm{cm}^{-1}\left(\mathbf{I}, f_{\text {osc }}=0.066\right)$ and $11661 \mathrm{~cm}^{-1}\left(\mathbf{I I}, f_{\text {osc }}=0.064\right)$ and $22409 \mathrm{~cm}^{-}$ ${ }^{1}$ (III, $\left.f_{\text {osc }}=0.094\right)$, with energies that agree to some extent with the experimental transitions (viz. $10100 \mathrm{~cm}^{-1}$ and $20400 \mathrm{~cm}^{-1}$ ) (see Figure S10). All of them have a multiconfigurational character that do not allow sharp conclusions, ${ }^{[19]}$ but it appears clearly from this analysis that I and II are essentially composed of LMCT and explain well broad intense transitions and dark coloured complexes. No other significant transition is predicted at lower energy which reinforces the picture of a localized $\mathrm{Ni}^{\mathrm{III}}$ center versus a delocalized system. $^{[4 a]}$
In summary, a nickel(II) complex incorporating an original tertbutyl substituted phosphasalen ligand was synthesized and characterized. Upon oxidation, this complex led to a high valent nickel(III) ${ }^{[20]}$ complex as demonstrated by X-ray, EPR, magnetism, and visible spectroscopy as well as DFT calculations. $\left[\mathbf{2}^{+}\right]\left[\mathbf{S b F}_{6}{ }^{-}\right]$is therefore one of the rare tetracoordinated $\mathrm{Ni}^{\mathrm{III}}$ complexes ${ }^{[15-16,18 \mathrm{a}, 21]}$ and to the best of our knowledge the only one featuring a phenoxide ligand. This observation markedly differs from precedents in the salen chemistry where $\mathrm{Ni}^{\mathrm{III}}$ complexes were observed at low temperature, in presence of additional ligands or anions. It can be rationalized by the better electron donating ability of iminophosphoranes compared to imines, and by the decreased electron density at the phenol rings which are substituted by an electron-demanding phosphorus atom. ${ }^{[12]}$ Preliminary investigations concerning the reactivity of $\left[\mathbf{2}^{+}\right]\left[\mathbf{S b F}_{6}{ }^{-}\right]$evidenced a fast oxidative ability that remains yet difficult to control. Our current efforts are devoted to this, considering a fine tuning of the ligand structure. Further studies will also focus on the oxidation of other phosphasalen complexes differing from $\mathbf{2}$ by the nature of the metal.

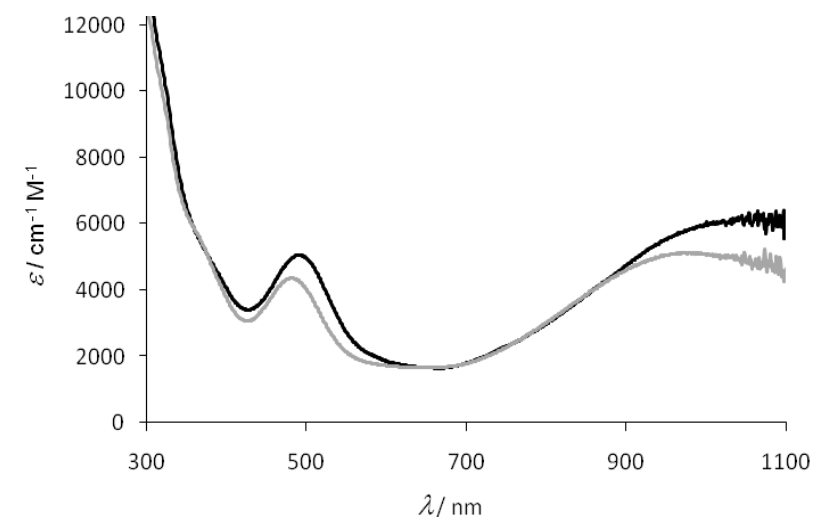

Figure 4. UV spectra of $\left[2^{+}\right]\left[\mathbf{S b F}_{6}^{-}\right]$in dichloromethane (black) and in toluene (grey).

\section{Experimental Section}

\section{Synthesis $\left[2^{+}\right]\left[\mathrm{SbF}_{6}^{-}\right]$}

Addition of $\mathrm{AgSbF}_{6}$ (34.4 mg, $0.1 \mathrm{mmol}$ ) into a solution of complex 2 (89.4 mg, $0.1 \mathrm{mmol}$ ) in $\mathrm{CH}_{2} \mathrm{Cl}_{2}(5 \mathrm{~mL}$ ) induced a rapid colour change from blue to deep red and precipitation of silver. After removal of $\mathrm{Ag}$ by centrifugation, dichloromethane was evaporated and the residue was dissolved in toluene $(1.5 \mathrm{~mL})$, giving a deep red-brown solution. Dark crystals were obtained after one week of storage at $-40^{\circ} \mathrm{C}$, which were then isolated by centrifugation and dried under reduced pressure. (104 mg, $95 \%$ ). ${ }^{1} \mathrm{H}$ NMR: $\delta 19.10$ (s, 2H, CH(OAr), 15.30 (s, $2 \mathrm{H}, \mathrm{CH}(\mathrm{Oar}), 8.31$ (s, br, 16H, CH(PPh $)), 7.20$ (s, br, 4H, CH(PPh $\left.\mathrm{PP}_{2}\right)$, $3.17\left(\mathrm{~s}, 18 \mathrm{H}, \mathrm{C}\left(\mathrm{CH}_{3}\right)_{3}\right), 2.50\left(\mathrm{~s}, 18 \mathrm{H}, \mathrm{C}\left(\mathrm{CH}_{3}\right)_{3}\right), 1.68\left(\mathrm{~s}, 2 \mathrm{H}, \mathrm{N}-\mathrm{CH}_{2-}\right.$ $\left.\mathrm{CH}_{2}-\mathrm{N}\right), 1.63\left(\mathrm{~s}, \mathrm{br}, 2 \mathrm{H}, \mathrm{N}-\mathrm{CH}_{2}-\mathrm{CH}_{2}-\mathrm{N}\right)$. Anal. Calcd for $\left[2^{+}\right]\left[\mathrm{SbF}_{6}^{-}\right]$ $\mathrm{C}_{54} \mathrm{H}_{64} \mathrm{~F}_{6} \mathrm{~N}_{2} \mathrm{NiO}_{2} \mathrm{P}_{2} \mathrm{Sb}: \mathrm{C}, 57.42 ; \mathrm{H}, 5.71 ; \mathrm{N}, 2.48$. Found: $\mathrm{C}, 57.50 ; \mathrm{H}$, $5.80 ; \mathrm{N}, 2.37$.

Received: ((will be filled in by the editorial staff)) Published online on ((will be filled in by the editorial staff))

Keywords: Iminophosphorane - nickel · one electron-oxidation · high valent metal $\cdot$ phosphasalen 
a)T. Katsuki, Coord. Chem. Rev. 1995, 140, 189-214; b)L. Canali, D. C. Sherrington, Chem. Soc. Rev. 1999, 28, 85-93; c)E. N. Jacobsen, Acc. Chem. Res. 2000, 33, 421-431; d)R. M. Haak, S. J. Wezenberg, A. W. Kleij, Chem. Commun. 2010, 46, 2713-2723. Y. D. Wang, J. L. DuBois, B. Hedman, K. O. Hodgson, T. D. P. Stack, Science 1998, 279, 537-540.

[3] a)T. Kurahashi, A. Kikuchi, Y. Shiro, M. Hada, H. Fujii, Inorg Chem. 2010, 49, 6664-6672; b)M. Orio, O. Jarjayes, H. Kanso, C. Philouze, F. Neese, F. Thomas, Angew. Chem.-Int. Edit. 2010, 49, 4989-4992; c)T. Kurahashi, H. Fujii, J. Am. Chem. Soc. 2011, 133, 8307-8316; d)A. Kochem, H. Kanso, B. Baptiste, H. Arora, C. Philouze, O. Jarjayes, H. Vezin, D. Luneau, M. Orio, F. Thomas, Inorg. Chem. 2012, 51, 10557-10571; e)R. C. Pratt, C. T. Lyons, E. C. Wasinger, T. D. P. Stack, J. Am. Chem. Soc. 2012, 134, 7367-7377.

a)T. Storr, E. C. Wasinger, R. C. Pratt, T. D. P. Stack, Angew. Chem.-Int. Edit. 2007, 46, 5198-5201; b)Y. Shimazaki, T. D. P. Stack, T. Storr, Inorg. Chem. 2009, 48, 8383-8392; c)Y. Shimazaki, N. Arai, T. J. Dunn, T. Yajima, F. Tani, C. F. Ramogida, T. Storr, Dalton Trans. 2011, 40, 2469-2479. a)C. Freire, B. de Castro, J. Chem. Soc.-Dalton Trans. 1998, 1491-1497; b)O. Rotthaus, F. Thomas, O. Jarjayes, C. Philouze, E. Saint-Aman, J. L. Pierre, Chem.-Eur. J. 2006, 12, 6953-6962; c)L. Benisvy, R. Kannappan, Y. F. Song, S. Milikisyants, M. Huber, I. Mutikainen, U. Turpeinen, P. Gamez, L. Bernasconi, E. J. Baerends, F. Hartl, J. Reedijk, Eur. J. Inorg. Chem. 2007, $637-$ 642.

Y. Shimazaki, F. Tani, K. Fukui, Y. Naruta, O. Yamauchi, J. Am. Chem. Soc. 2003, 125, 10512-10513.

[7] A. Kochem, M. Orio, O. Jarjayes, F. Neese, F. Thomas, Chem. Commun. 2010, 46, 6765-6767.

[8] a)O. Rotthaus, O. Jarjayes, C. P. Del Valle, C. Philouze, F. Thomas, Chem. Commun. 2007, 4462-4464; b)L. Chiang, A. Kochem, O. Jarjayes, T. J. Dunn, H. Vézin, M. Sakaguchi, T. Ogura, M. Orio, Y. Shimazaki, F. Thomas, T. Storr, Chem.-Eur. J. 2012, 18, 14117-14127.

[9] T. Storr, P. Verma, Y. Shimazaki, E. C. Wasinger, T. D. P. Stack, Chem.-Eur. J. 2010, 16, 8980-8983.

[10] E. M. Broderick, N. Guo, C. S. Vogel, C. Xu, J. Sutter, J. T. Miller, K. Meyer, P. Mehrkhodavandi, P. L. Diaconescu, J. Am. Chem. Soc. 2011, 133, 9278-9281.

[11] a)A. Buchard, A. Auffrant, C. Klemps, L. Vu-Do, L. Boubekeur, X. F. Le Goff, P. Le Floch, Chem. Commun. 2007, 1502-1504; b)A. Buchard, B. Komly, A. Auffrant, X. F. Le Goff, P. Le Floch, Organometallics 2008, 27, 4380-4385; c)A. Buchard, A. Auffrant, L. Ricard, X. F. Le Goff, R. H. Platel, C. K. Williams, P. Le Floch, Dalton Trans. 2009, 10219-10222; d)T. P. A. Cao, E.
Payet, A. Auffrant, X. F. Le Goff, P. Le Floch, Organometallics 2010, 29, 3991-3996.

[12] T. P. A. Cao, S. Labouille, A. Auffrant, Y. Jean, X. F. Le Goff, P. Le Floch, Dalton Trans. 2011, 40, 10029-10037.

[13] a)C. Bakewell, T. P. A. Cao, N. Long, X. F. Le Goff, A. Auffrant, C. K. Williams, J. Am. Chem. Soc. 2012, 20577-20580; b)T. P. A. Cao, A. Buchard, X. F. Le Goff, A. Auffrant, C. K. Williams, Inorg. Chem. 2012, 51, 2157-2169; c)C. Bakewell, T. P. A. Cao, N. Long, X. F. Le Goff, A. Auffrant, C. K. Williams, Organometallics 2013, 32, 1475-1483.

[14] Y. Shimazaki, T. Yajima, F. Tani, S. Karasawa, K. Fukui, Y. Naruta, O. Yamauchi, J. Am. Chem. Soc. 2007, 129, 2559-2568.

[15] V. M. Iluc, A. J. M. Miller, J. S. Anderson, M. J. Monreal, M. P. Mehn, G. L. Hillhouse, J. Am. Chem. Soc. 2011, 133, 1305513063.

[16] P. J. Alonso, A. B. Arauzo, M. A. Garcia-Monforte, A. Martin, B. Menjon, C. Rillo, M. Tomas, Chem.-Eur. J. 2009, 15, 1102011030 .

[17] B. R. McGarvey, Can. J. Chem.-Rev. Can. Chim. 1975, 53, 24982511.

[18] a)T. J. Collins, T. R. Nichols, E. S. Uffelman, J. Am. Chem. Soc. 1991, 113, 4708-4709; b)Y. H. Huang, J. B. Park, M. W. W. Adams, M. K. Johnson, Inorg. Chem. 1993, 32, 375-376.

[19] T. R. Dugan, E. Bill, K. C. Macleod, G. J. Christian, R. E. Cowley, W. W. Brennessel, S. Ye, F. Neese, P. L. Holland, J. Am. Chem. Soc. 2012, 134, 20352-20364.

[20] For examples of pentacoordinated $\mathrm{Ni}^{\mathrm{III}}$ complexes see a)D. M. Grove, G. Vankoten, P. Mul, R. Zoet, J. G. M. Vanderlinden, J. Legters, J. E. J. Schmitz, N. W. Murrall, A. J. Welch, Inorg. Chem. 1988, 27, 2466-2473; b)A. W. Kleij, R. A. Gossage, R. Gebbink, N. Brinkmann, E. J. Reijerse, U. Kragl, M. Lutz, A. L. Spek, G. van Koten, J. Am. Chem. Soc. 2000, 122, 12112-12124; c)A. T. Fiedler, T. C. Brunold, Inorg. Chem. 2007, 46, 85118523; d)C. M. Lee, C. H. Chen, F. X. Liao, C. H. Hu, G. H. Lee, J. Am. Chem. Soc. 2010, 132, 9256-9258; e)M. Gennari, M. Orio, J. Pecaut, E. Bothe, F. Neese, M. N. Collomb, C. Duboc, Inorg. Chem. 2011, 50, 3707-3716; f)W. Z. Lee, C. W. Chiang, T. H. Lin, T. S. Kuo, Chem.-Eur. J. 2012, 18, 50-53.

[21] M. I. Lipschutz, X. Yang, R. Chatterjee, T. D. Tilley, J. Am. Chem. Soc. 2013, DOI: 10.1021/ja408151h. 
Entry for the Table of Contents (Please choose one layout)
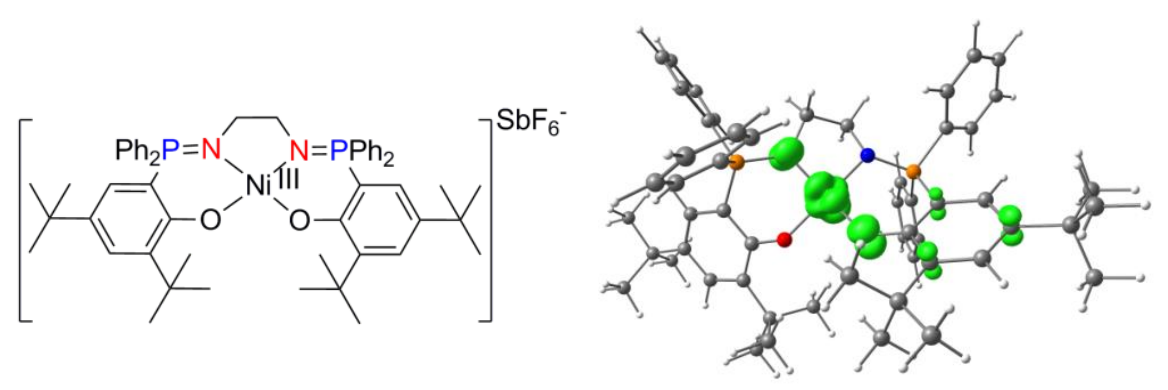

\section{$\mathrm{P}=\mathrm{N}$ does not equal $\mathrm{C}=\mathrm{N}$ !}

One electron oxidation of a nickel(II) complex incorporating an original phosphasalen ligand ('Bu-Psalen) leads to a rare tetracoordinated $\mathrm{Ni}{ }^{\prime \prime \prime}$ complex.

The oxidation locus is demonstrated by the use of various spectroscopic tools such as X-ray, EPR, magnetism, and visible spectroscopy as well as with DFT calculations. 
The oxidation of a nickel(II) complex bearing a tetradentate phosphasalen ligand, which differs from salen by the presence of iminophosphoranes $(P=N)$ in place of imines, was easily achieved by addition of a silver salt. The locus of this oxidation was investigated with a combination of different techniques (NMR, EPR, UV spectroscopy, X-ray crystallography, magnetism measurement) as well as DFT calculations. All data are in agreement with a high valent nickel(III) center concentrating the spin density. This markedly differs from precedents in the salen series for which oxidation on the metal was only observed at low temperature or in presence of additional ligands or anions. Therefore, thanks to the good electron donating properties of the phosphasalen ligand, [Ni(Psalen) $]^{+}$represents a rare example of a tetracoordinated high valent nickel complex in presence of a phenoxide ligand. 